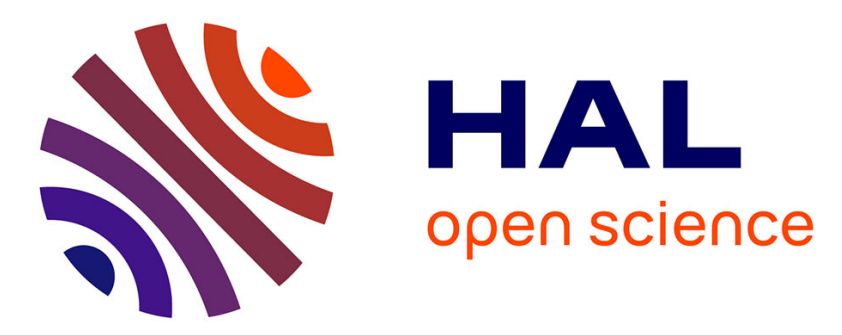

\title{
Could propranolol be beneficial in adult cerebral cavernous malformations?
}

Caroline Apra, Chloé Dumot, Pierre Bourdillon, Isabelle Pelissou-Guyotat

\section{To cite this version:}

Caroline Apra, Chloé Dumot, Pierre Bourdillon, Isabelle Pelissou-Guyotat. Could propranolol be beneficial in adult cerebral cavernous malformations?. Neurosurgical Review, In press, 10.1007/s10143018-01074-0 . hal-01983098

\section{HAL Id: hal-01983098 https://hal.sorbonne-universite.fr/hal-01983098}

Submitted on 16 Jan 2019

HAL is a multi-disciplinary open access archive for the deposit and dissemination of scientific research documents, whether they are published or not. The documents may come from teaching and research institutions in France or abroad, or from public or private research centers.
L'archive ouverte pluridisciplinaire HAL, est destinée au dépôt et à la diffusion de documents scientifiques de niveau recherche, publiés ou non, émanant des établissements d'enseignement et de recherche français ou étrangers, des laboratoires publics ou privés. 


\title{
Could propranolol be beneficial in adult cerebral cavernous malformations?
}

\author{
Caroline Apra ${ }^{1,2,3}$ (D) Chloé Dumot $^{3,4} \cdot$ Pierre Bourdillon $^{2,3} \cdot$ Isabelle Pelissou-Guyotat $^{3,4}$
}

\begin{abstract}
Surgery is the only therapeutic option for cerebral cavernous malformations (CCM) and is proposed, whenever possible, after haemorrhagic events, neurological symptoms, or epilepsy, radiosurgery being a controversial alternative in some cases. However, there is no treatment for non-accessible lesions, such as brainstem CCM, multiple CCM, or those located in functional areas. Propranolol, a non-selective beta-blocker used as first-line treatment for infantile haemangiomas, has proved spectacularly effective in a few cases of adult patients with CCM. We herein review the histological, in vitro data and clinical findings that support the idea of propranolol as a potential treatment for CCM. Since one retrospective study has not been conclusive, we support the idea that prospective trials are necessary.
\end{abstract}

Keywords Cavernomas $\cdot$ Cavernous malformations $\cdot$ Cavernous angiomas $\cdot$ Cavernous haemangiomas $\cdot$ Beta-blocker

\section{Introduction}

Cerebral cavernous malformations $(\mathrm{CCM})$ are rare but potentially deadly vascular malformations. They have a prevalence of 0.16 to $0.5 \%$ with a mean age of presentation of $30[1,2]$. The lesions can develop anywhere in the central nervous system, with up to $18 \%$ located in the brainstem [3]. They occur as multiple lesions in $20 \%$ of cases [4], mostly in familial cavernomatosis due to loss of function of CCM1, CCM2, or CCM3 genes [5-7].

The most important clinical feature seems to be the yearly haemorrhage rate, which is very heterogeneous throughout studies, around $2.4 \%$ per patient-year $(1.6 \%-3.1 \%)$ and $0.7 \%$ per lesion-year. This rate is lower in patients with incidental CCM $(0.08 \%-0.2 \%)$ and those with unruptured CCM

Caroline Apra and Chloé Dumot contributed equally to this work.

Caroline Apra

caroline.apra@neurochirurgie.fr

1 Sorbonne Université, Université Pierre et Marie Curie, Paris, France

2 Brain and Spine Institute, INSERM U1127, CNRS, UMR7225, Paris, France

3 Hospices Civils de Lyon, Neurology \& Neurosurgery Hospital Pierre Wertheimer, Department of Neurosurgery, Lyon, France

4 University of Lyon, Université Claude Bernard, Lyon, France
$(0.3 \%-0.6 \%)$ [8]. However, once a patient suffers an initial symptomatic haemorrhage, the re-bleeding rate increases to $4.5 \%$ for cortical lesion and $22.9 \%$ for brain stem lesions [8, 9]. Likewise, Zabramski et al. classified CCM lesions into 4 categories based on MRI findings and found an increased risk of recurrent haemorrhage in those patients with imaging evidence of recent bleeding. [10].

Most patients referred to the neurosurgical clinic have had a symptomatic haemorrhage. Common presentations include epilepsy (37\%), haemorrhage (36\%), headache (23\%), or neurological deficits (22\%); however, more $30 \%$ of patients are asymptomatic or complaining only of nonspecific headache [3]. A proportion of patients with incidental finding of CCM also do not present to a specialised clinic.

The management of patients with CCM is based on surgical resection, observation, symptomatic treatments and, more controversially, radiosurgery. Surgical indications depend on the anatomical location of the malformation, classically separated into telencephalic or brainstem, and the symptoms (Cf. Fig. 1and 2). In telencephalic CCM with a history of bleeding, resection is indicated if the CCM is superficial or functionally accessible. Patients with CCM-related epilepsy only may first benefit from an antiepileptic drug and surgery is considered if it is easily accessible or in case of persistent seizures [11]. Surgery may also be indicated for patients with exophytic brainstem CCM and multiple haemorrhages, although postoperative morbidity is as high as $43 \%[12,13]$. 

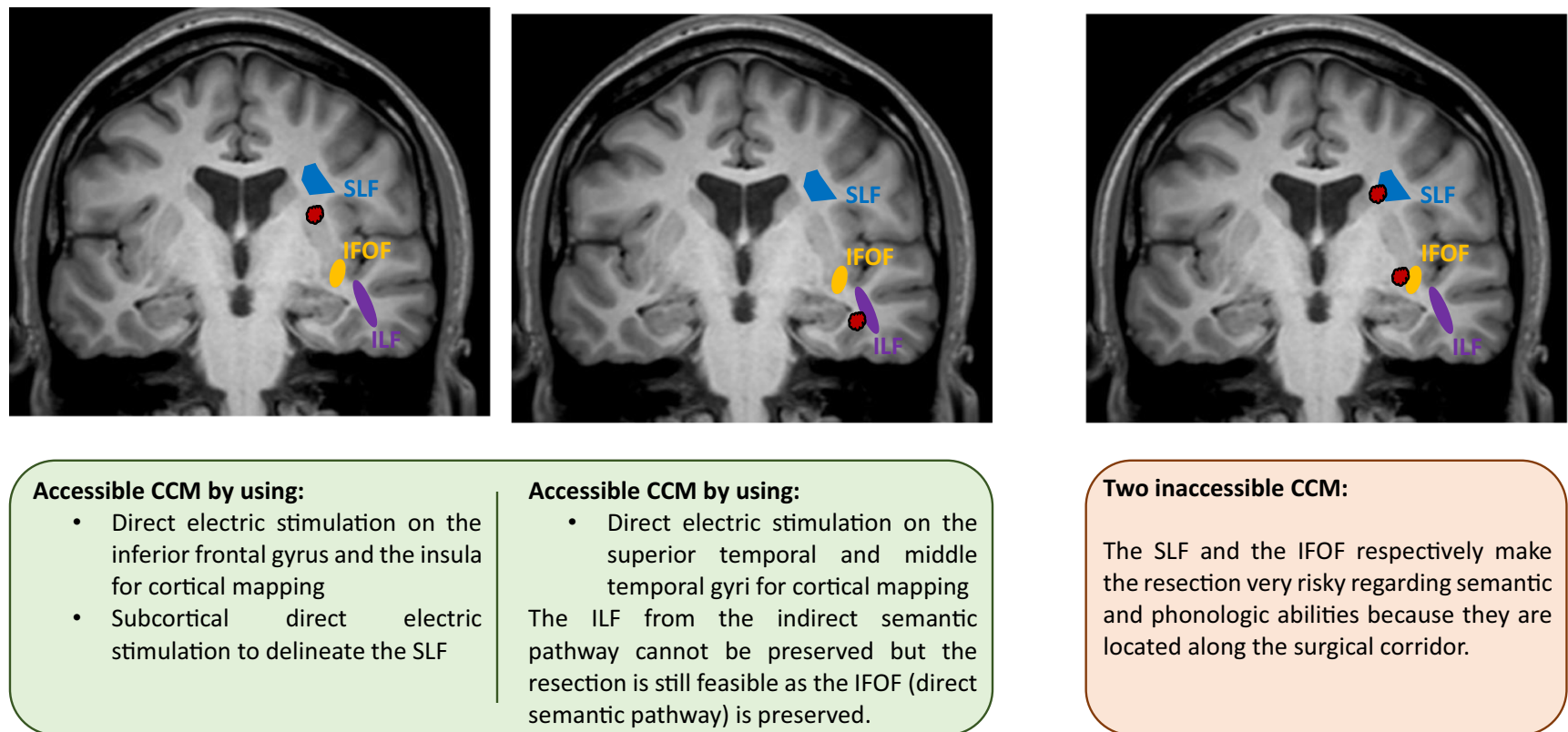

Fig. 1 Three examples for CCM identically deep but variously accessible ( $a, b$ accessible; $c$ not accessible because of the high functional risk). The $\mathrm{CCM}$ is represented in red. SLF, superior longitudinal fasciculus (in blue); ILF, inferior longitudinal fasciculus (in purple); IFOF, inferior fronto-occipital fasciculus (in orange)
Despite this therapeutic array, CCM often remain a therapeutic challenge and patients with brainstem, or multiple lesions, or lesions located in functional areas, lack efficient therapies. Alternative medical treatments are being evaluated, including statins (NCT01764451, NCT02603328), antiangiogenic drugs, and Vitamin D3, but none of them has proven beneficial [14-17]. The use of non-selective beta-blocker propranolol has recently been described. Since no clinical study has been tackling this issue yet, we offer to review whether and why propranolol could be helpful in patients with CCM.

\section{Material and methods}

We searched PubMed and ClinicalTrials.gov for the terms "cerebral cavernous malformations" or "cerebral cavernomas" or "cavernous angiomas" or "cavernous haemangiomas" and "propranolol" or "beta-blockade" or "beta-blocker". We included in this review all information relevant to the efficacy of propranolol in adults with CCM, including case reports and in vitro screening.

\section{Results}

Treating patients with CCM with propranolol was first proposed in 2011 by Filippidis et al. and in 2013 by Strahle et al. who suggested it might be beneficial in some types of children intracranial haemangiomas $[18,19]$. This idea was first based on its spectacular efficacy in infantile skin capillary haemangiomas, an effect that was discovered by serendipity in 2008: two infants with severe haemangiomas were treated with propranolol for a cardiopathy and their malformations considerably decreased within a few days, until they became completely flat [20]. In a few years only, propranolol has become the first-line treatment for complicated infantile haemangiomas affecting for instance the liver, the eyes, the thyroid, the medullary canal, or the skin [21]. It is effective in at least $80 \%$ of cases [22].

CCM, like infantile haemangiomas, are composed of a mixture of abnormal dilated capillary vessels with disorganised endothelial cells and pericytes [23, 24]. In infantile haemangiomas, several mechanisms have been explored, that probably play a part in the malformation decrease after propranolol treatment: vasoconstriction, decreased expression of basic fibroblast growth factor and vascular endothelial growth factor, triggering of apoptosis in capillary endothelial cells, inhibition of migration, proliferation, and reorganisation of endothelial cells $[20,25,26]$. A common precursor cell for propranolol-sensitive vascular tumours, including infantile haemangiomas and CCM, could be CD15-positive cells usually found in the placental vessels. These cells remain in the vessels walls and could serve as a potential reserve of vasculogenic progenitors to be recruited in pre- and postnatal situations [24]. Based on these similarities, propranolol was used to treat infantile CCM in 2010 [27].

Propranolol is a non-selective beta-blocker. It is commonly indicated as a treatment for heart failure, elevated blood pressure, and anxiety. Contraindications include chronic obstructive pulmonary disease, asthma, acute heart failure, some 
Fig. 2 Examples of CCM locations on T2-weighted brain MRI, surgically inaccessible (a, b), accessible with high functional risk (c, d), and relatively easy to access (e, f). a Endophytic brainstem CCM. b CCM in the right thalamus and internal capsule. c Exophytic brainstem CCM in the left cerebellar peduncle. $\mathbf{d}$ Left frontal CCM, located next to the zone activated for talking on functional MRI. e Right cerebellar CCM. f Right frontal CCM. Propranolol could be proposed to patients $\mathbf{a}$ and $\mathbf{b}$ in which radiosurgery is the only available therapeutic alternative
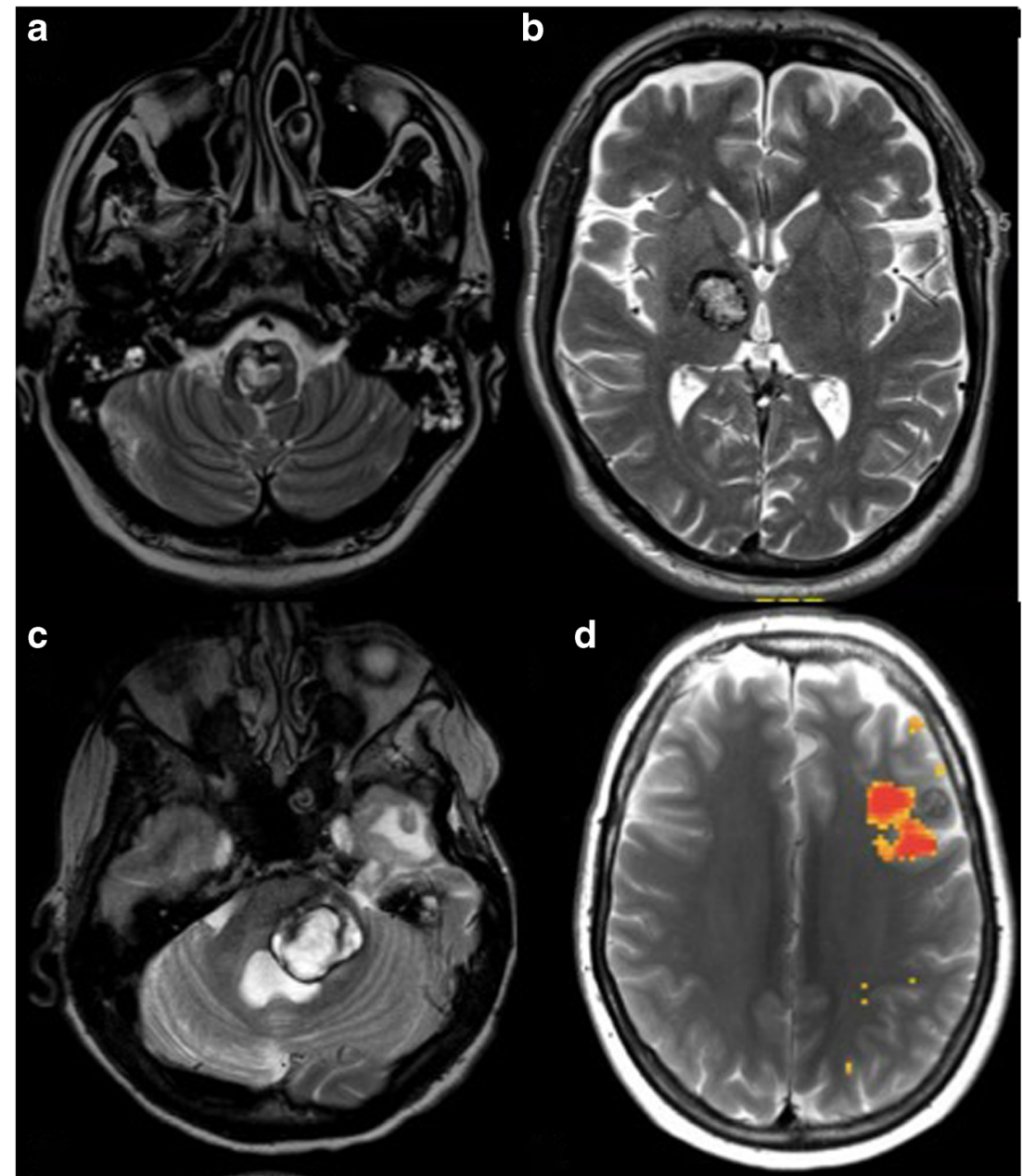

$\theta$

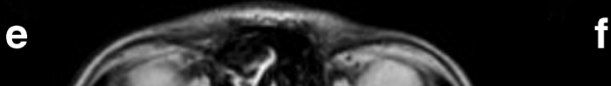

f

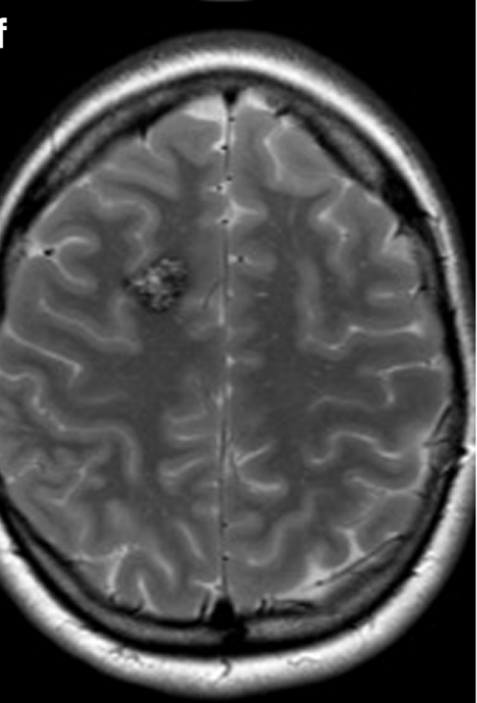

arrhythmias including bradycardia, cirrhosis, Raynaud's syndrome, and is not advised during breastfeeding [28]. On the other hand, propranolol is very well tolerated: the most frequent side effects are fatigue, bradycardia, sleep disturbances $(<10 \%$ of patients), and digestive troubles $(<1 \%)$. Neurological effects are very rare $(<0.1 \%)$ and include paraesthesia, hallucinations, psychosis, mood disturbances, and confusion.

In 2015, Gibson et al. carried out an in vitro study to screen a range of 2100 molecules and repurpose treatments for CCM [14]. Pindolol, a non-selective beta-adrenergic receptor antagonist, was among the top 7 drugs that were effective in vitro. 
These molecules were able to rescue a normal structure to CCM2-deficient cells cultures, and a functional phenotype in terms of trans-cellular resistance. Therefore, the authors explicitly confirm that it could be a relevant therapeutic compound. However, they could not test it in their loss-of-CCM2 mouse model due to the time and cost associated.

In clinical practice, propranolol has only been reported in a few case reports and, to the best of our knowledge, it is not commonly prescribed. First, propranolol was effectively used in children harbouring infantile brain haemangiomas, ranging from so-called cavernous lesions to capillary haemangiomas [27, 29-32]. In these patients, the histological nature of the lesions was not clear, but the success of the treatment encouraged using it in dramatic adult cases who could not be operated (cf. Table 1) [10, 33].

1-A 55-year-old woman suffered from multiple familial CCM with several operations for haemorrhagic lesions. After 22 years of evolution, the clinical situation worsened following the repeated bleeding of an internal capsule lesion non-accessible to surgery and the onset of a new focus of acute bleeding, prompting the patient to receive oral propranolol $20 \mathrm{mg} 3 \times /$ day. After 14 months, MRI showed marked reduction of the previously haemorrhagic lesion. Propranolol was decreased to $20 \mathrm{mg} /$ day and discontinued after 1 year. MRI was stable after 2 years, without further symptom. Propranolol was well tolerated.
2-The second patient is a 58 -year-old woman with an occipital CCM evolving for 2 years, revealed by worsening headaches and visual symptoms. Imaging confirmed repeated acute haemorrhage and increase in the size of the lesion with perilesional oedema during this period (from $1.5 \mathrm{~cm}$ up to $5.2 \mathrm{~cm}$ ). When offered surgery, the patient declined it and she received propranolol $20 \mathrm{mg} 3 \times / /$ day. MRI after 3 and 9 months showed progressive reduction of the lesion to $2.8 \mathrm{~cm}$ and resolution of oedema. However, the patient was morbidly obese and reported shortness of breath, imputable to propranolol. Propranolol was decreased to $20 \mathrm{mg} /$ day after 14 months and discontinued 4 months later. Rapidly after stopping the treatment, the authors report the onset of headaches and significant enlargement of the CCM, with signs of acute haemorrhage and surrounding oedema, worsening on 2 MRIs within 7 weeks. The patient finally agreed to surgical resection and pathological examination confirmed the diagnosis of CCM.

3-A 22-year-old man with mild von Willebrand disease presented with two occipital CCM, one with acute bleeding, revealed by headache and intermittent visual disturbance. Over a period of 54 months, 26 episodes of haemorrhage occurred in several CCM, including new ones, despite multiple treatment attempts (surgical resection of a CCM with compressive brainstem hematoma, thalidomide, simvastatin, haemostatic factors). Finally, propranolol was started at the dose of $30 \mathrm{mg}$ daily. From this moment, the occurrence of new CCM with

Table 1 Recapitulation of cases of adult patients treated with propranolol for CCM

\begin{tabular}{|c|c|c|c|c|c|c|c|c|}
\hline Article & $\begin{array}{l}\text { Types of } \\
\text { lesions }\end{array}$ & $\begin{array}{l}\text { Clinical and MRI } \\
\text { status }\end{array}$ & $\begin{array}{l}\text { Delay } \\
\text { between } \\
\text { diagnosis } \\
\text { and } \\
\text { treatment }\end{array}$ & Dose & Clinical effect & MRI effect & $\begin{array}{l}\text { Delay } \\
\text { between } \\
\text { treatment } \\
\text { and first } \\
\text { effect }\end{array}$ & $\begin{array}{l}\text { Duration of } \\
\text { treatment }\end{array}$ \\
\hline $\begin{array}{l}\text { Zabramski } \\
2016\end{array}$ & $\begin{array}{l}\text { A } 55 \text {-year-old } \\
\text { woman, } \\
\text { familial } \\
\text { multiple } \\
\text { CCMs, } \\
\text { previously } \\
\text { operated }\end{array}$ & $\begin{array}{l}\text { Clinical } \\
\text { worsening, } \\
\text { repeated } \\
\text { bleeding, new } \\
\text { focuses of } \\
\text { acute } \\
\text { haemorrhage } \\
\text { and oedema }\end{array}$ & 22 years & $\begin{array}{l}20 \mathrm{mg} \\
\times 3 / \text { day } \\
\text { for } \\
14 \mathrm{mon}- \\
\text { ths then } \\
20 \mathrm{mg} /- \\
\text { day }\end{array}$ & $\begin{array}{l}\text { No more } \\
\text { neurological } \\
\text { event }\end{array}$ & $\begin{array}{l}\text { Reduction of the previously } \\
\text { haemorrhagic lesion. No } \\
\text { sign of new } \\
\text { haemorrhage. Sequelae } \\
\text { of "innumerable CCMs" } \\
\text { on gradient-echo MRI. }\end{array}$ & $\begin{array}{l}14 \text { months } \\
\text { (MRI) }\end{array}$ & $\begin{array}{l}26 \text { months, } \\
\text { then } \\
\text { stable }\end{array}$ \\
\hline $\begin{array}{l}\text { Zabramski } \\
2016\end{array}$ & $\begin{array}{l}\text { A 57-year-old } \\
\text { woman, } \\
\text { occipital } \\
\text { CCM, not } \\
\text { operated }\end{array}$ & $\begin{array}{l}\text { Repeated } \\
\text { haemorrhage, } \\
\text { clinical } \\
\text { worsening. }\end{array}$ & 2 years & $\begin{array}{l}20 \mathrm{mg} \\
\times 3 / \text { day } \\
\text { for } \\
14 \mathrm{mon}- \\
\text { ths then } \\
20 \mathrm{mg} /- \\
\text { day }\end{array}$ & $\begin{array}{l}\text { Neurological } \\
\text { improvement } \\
\text { (headaches). } \\
\text { Shortness of } \\
\text { breath. }\end{array}$ & $\begin{array}{l}\text { Reduction of the lesion and } \\
\text { oedema. }\end{array}$ & $\begin{array}{l}3 \text { months } \\
\text { (MRI) }\end{array}$ & $\begin{array}{l}18 \text { months, } \\
\text { not well } \\
\text { tolerated } \\
\text { (morbidly } \\
\text { obese } \\
\text { patient) }\end{array}$ \\
\hline $\begin{array}{l}\text { Reinhard } \\
2016\end{array}$ & $\begin{array}{l}\text { A } 22 \text {-year-old } \\
\text { man, } \\
\text { multiple } \\
\text { CCMs, not } \\
\text { familial, } \\
\text { previously } \\
\text { operated }\end{array}$ & $\begin{array}{l}\text { Clinical } \\
\text { worsening, } \\
\text { repeated } \\
\text { bleeding, } 26 \\
\text { new CCM }\end{array}$ & 54 months & $30 \mathrm{mg} /$ day & $\begin{array}{l}\text { No more } \\
\text { neurological } \\
\text { event }\end{array}$ & $\begin{array}{l}\text { Immediate stability of the } \\
\text { progressing lesions. No } \\
\text { more bleeding. }\end{array}$ & $\begin{array}{l}0 \text { (clinical } \\
\quad \text { examina- } \\
\text { tion and } \\
\text { MRI) }\end{array}$ & $>26$ months \\
\hline
\end{tabular}


haemorrhages stopped completely. The patient was free of any other neurological event for the next 26 months without any other medication. Propranolol was well tolerated. In this patient, genetic testing did not reveal $C C M$ mutations.

In the reported patients, propranolol has shown beneficial effects on both the number of lesions, their volume, and the onset of haemorrhage, even in long-lasting lesions. The dose and duration of treatment and follow-up was different in all reported cases, ranging from 6 months in infants to several years. Although propranolol was stopped without complication in one patient, its discontinuation caused rapid deterioration in another.

\section{Discussion}

The hypothetical mechanism of action of propranolol in CCM is not clearly understood but the impressive responses in a few patients and the absence of available therapeutic options in many cases would make it worthwhile to evaluate objectively the efficacy of propranolol for the treatment of CCM, the risks and cost associated with this treatment being extremely low. If effective, propranolol could obviously be beneficial in patients with inaccessible brainstem CCM. It could also be proposed to patients with non-surgical telencephalic CCM, either alone or in addition to an antiepileptic drug when needed. However, the unpredictability of CCM haemorrhages making it highly complicated to evaluate the efficacy of any treatment for this disease, one should keep it in mind when considering the cases that have been reported so far: the bleedings often occur as a cluster, and some lesions may involve spontaneously on MRI. A recent retrospective cohort study evaluated the risk of bleeding in patients with CCM treated with betablockers for unrelated indications. The authors found no evidence that beta-blockers reduced or increased the risk of CCM-related haemorrhage [34]. This study follows 408 patients over a mean follow-up period of 3.7 years, which is short, as mentioned by the authors, compared to the natural history of CCM. Moreover, the subgroup treated by betablockers is highly heterogeneous, with only 136 of the patients having any history or prior haemorrhage, and treated with 8 different drugs at varied daily doses [34]. Only 3 CCM patients received unselective beta-blockers (propranolol or oxprenolol), preventing any meaningful analysis. More unbiased data are needed to show or rule out an effect, and this cohort study shows that only comparative prospective studies with sufficient statistical power will give the possibility to answer. Prospective studies in life-threatening cases are ethically acceptable since there is absolutely no effective therapeutic alternative. The follow-up of these patients will require frequent clinical and MRI follow-up with long-term evaluation since CCM natural evolution is chronic and unpredictable, and comparison with a control group. Three clinical trials have just started in the USA and in Italy: two of them are randomised prospective trials offering propranolol versus placebo/nothing to patients with surgically inaccessible CCM (NCT03523650, NCT03589014), the other is comparing mRNA expression in patients operated for $\mathrm{CCM}$, having received preoperative propranolol or not (NCT03474614).

\section{Conclusion}

Many patients with life-threatening CCM cannot benefit from the current treatments, urging to find new non-invasive options. Few but spectacular reports, supported by preliminary in vitro data and by the analogy with infantile angiomas, suggest that propranolol may be a promising medical option. Ongoing prospective trials will probably help find a therapeutic answer based on surgical and medical possibilities, adapted to the specificities of brainstem or telencephalic CCM.

\section{Compliance with ethical standards}

Conflict of interest The authors declare that they have no conflict of interest.

Ethical approval This article does not contain any studies with human participant or animals and complies with French ethical standards.

Informed consent This article does not contain any studies with human participants performed by any of the authors. This article has never been published or presented previously.

\section{References}

1. Flemming KD, Graff-Radford J, Aakre J, Kantarci K, Lanzino G, Brown RD Jr, Mielke MM, Roberts RO, Kremers W, Knopman DS, Petersen RC, Jack CR Jr (2017) Population-based prevalence of cerebral cavernous malformations in older adults: Mayo Clinic study of aging. JAMA Neurol 74:801-805. https://doi.org/10.1001/ jamaneurol.2017.0439

2. Akers A, Al-Shahi Salman R, A Awad I et al (2017) Synopsis of guidelines for the clinical management of cerebral cavernous malformations: consensus recommendations based on systematic literature review by the Angioma Alliance scientific advisory board clinical experts panel. Neurosurgery 80:665-680. https://doi.org/ 10.1093/neuros/nyx091

3. Gross BA, Lin N, Du R, Day AL (2011) The natural history of intracranial cavernous malformations. Neurosurg Focus 30:E24. https://doi.org/10.3171/2011.3.FOCUS1165

4. Kondziolka D, Lunsford LD, Kestle JR (1995) The natural history of cerebral cavernous malformations. J Neurosurg 83:820-824. https://doi.org/10.3171/jns.1995.83.5.0820

5. Akers AL, Johnson E, Steinberg GK, Zabramski JM, Marchuk DA (2009) Biallelic somatic and germline mutations in cerebral cavernous malformations (CCMs): evidence for a two-hit mechanism of CCM pathogenesis. Hum Mol Genet 18:919-930. https://doi.org/ 10.1093/hmg/ddn430

6. Fischer A, Zalvide J, Faurobert E, Albiges-Rizo C, TournierLasserve E (2013) Cerebral cavernous malformations: from CCM 
genes to endothelial cell homeostasis. Trends Mol Med 19:302308. https://doi.org/10.1016/j.molmed.2013.02.004

7. Gault J, Shenkar R, Recksiek P, Awad IA (2005) Biallelic somatic and germ line CCM1 truncating mutations in a cerebral cavernous malformation lesion. Stroke 36:872-874. https://doi.org/10.1161/ 01.STR.0000157586.20479.fd

8. Gross BA, Du R (2015) Cerebral cavernous malformations: natural history and clinical management. Expert Rev Neurother 15:771777. https://doi.org/10.1586/14737175.2015.1055323

9. Taslimi S, Modabbernia A, Amin-Hanjani S, Barker FG II, Macdonald RL (2016) Natural history of cavernous malformation: systematic review and meta-analysis of 25 studies. Neurology 86: 1984-1991. https://doi.org/10.1212/WNL.0000000000002701

10. Zabramski JM, Kalani MYS, Filippidis AS, Spetzler RF (2016) Propranolol treatment of cavernous malformations with symptomatic hemorrhage. World Neurosurg 88:631-639. https://doi.org/10. 1016/j.wneu.2015.11.003

11. Rosenow F, Alonso-Vanegas MA, Baumgartner C, Blümcke I, Carreño M, Gizewski ER, Hamer HM, Knake S, Kahane P, Lüders HO, Mathern GW, Menzler K, Miller J, Otsuki T, Özkara C, Pitkänen A, Roper SN, Sakamoto AC, Sure U, Walker MC, Steinhoff BJ, The Surgical Task Force, Commission on Therapeutic Strategies of the ILAE (2013) Cavernoma-related epilepsy: review and recommendations for management-report of the surgical task force of the ILAE commission on therapeutic strategies. Epilepsia 54:2025-2035. https://doi.org/10.1111/epi.12402

12. Abla AA, Lekovic GP, Turner JD, de Oliveira JG, Porter R, Spetzler RF (2011) Advances in the treatment and outcome of brainstem cavernous malformation surgery: a single-center case series of 300 surgically treated patients. Neurosurgery 68:403-414; discussion 414-415. https://doi.org/10.1227/NEU.0b013e3181ff9cde

13. Gross BA, Batjer HH, Awad IA, Bendok BR, du R (2013) Brainstem cavernous malformations: 1390 surgical cases from the literature. World Neurosurg 80:89-93. https://doi.org/10.1016/j. wneu.2012.04.002

14. Gibson CC, Zhu W, Davis CT, Bowman-Kirigin JA, Chan AC, Ling J, Walker AE, Goitre L, Delle Monache S, Retta SF, Shiu YTE, Grossmann AH, Thomas KR, Donato AJ, Lesniewski LA, Whitehead KJ, Li DY (2015) Strategy for identifying repurposed drugs for the treatment of cerebral cavernous malformation. Circulation 131:289-299. https://doi.org/10.1161/ CIRCULATIONAHA.114.010403

15. Leblanc GG, Golanov E, Awad IA, Young WL (2009) Biology of vascular malformations of the brain. Stroke 40:e694-e702. https:// doi.org/10.1161/STROKEAHA.109.563692

16. Shenkar R, Shi C, Austin C, Moore T, Lightle R, Cao Y, Zhang L, Wu M, Zeineddine HA, Girard R, McDonald DA, Rorrer A, Gallione C, Pytel P, Liao JK, Marchuk DA, Awad IA (2017) RhoA kinase inhibition with fasudil versus simvastatin in murine models of cerebral cavernous malformations. Stroke 48:187-194. https://doi.org/10.1161/STROKEAHA.116.015013

17. Wüstehube J, Bartol A, Liebler SS, Brütsch R, Zhu Y, Felbor U, Sure U, Augustin HG, Fischer A (2010) Cerebral cavernous malformation protein CCM1 inhibits sprouting angiogenesis by activating DELTA-NOTCH signaling. Proc Natl Acad Sci U S A 107: 12640-12645. https://doi.org/10.1073/pnas.1000132107

18. Filippidis AS, Fountas KN, Kalani MYS, Zabramski JM, Spetzler RF (2011) Letter by Filippidis et al regarding article, "Evaluating strategies for the treatment of cerebral cavernous malformations.". Stroke 42:e373-e373. https://doi.org/10.1161/STROKEAHA.110. 606251

19. Strahle J, Odden AJ, Maher CO, Garton HJL (2013) Letter to the editor: hemangiomas and propranolol. J Neurosurg Pediatr 12:418. https://doi.org/10.3171/2013.6.PEDS13284
20. Léauté-Labrèze C, Dumas de la Roque E, Hubiche T et al (2008) Propranolol for severe hemangiomas of infancy. N Engl J Med 358: 2649-2651. https://doi.org/10.1056/NEJMc0708819

21. Smithson SL, Rademaker M, Adams S, Bade S, Bekhor P, Davidson S, Dore A, Drummond C, Fischer G, Gin A, Grills C, Halbert A, Lokmic Z, McCahon E, Morgan VA, Murrell DF, Orchard D, Penington A, Purvis D, Relic J, Robertson S, Robinson AJ, Scardamaglia L, Su J, Tan S, Wargon O, Warren L, Wong LC, Zappala T, Phillips R (2017) Consensus statement for the treatment of infantile haemangiomas with propranolol. Australas J Dermatol 58:155-159. https://doi.org/10.1111/ajd.12600

22. Kaneko T, Sasaki S, Baba N, Koh K, Matsui K, Ohjimi H, Hayashi N, Nakano A, Ohki K, Kuwano Y, Morimoto A, Tamaki Z, Kakazu M, Kishi K, Oyama T, Sato A, Kato R, Higuchi T (2017) Efficacy and safety of oral propranolol for infantile hemangioma in Japan. Pediatr Int 59:869-877. https://doi.org/10.1111/ped.13318

23. Mosnier J-F, Brunon J, Nuti C (2007) Histopathology of central nervous system cavernomas. Neurochirurgie 53:131-135. https:// doi.org/10.1016/j.neuchi.2007.02.004

24. Seidmann L, Anspach L, Roth W (2016) The embryo-placental CD15-positive "vasculogenic zones" as a source of propranololsensitive pediatric vascular tumors. Placenta 38:93-99. https://doi. org/10.1016/j.placenta.2015.12.013

25. Annabi B, Lachambre M-P, Plouffe K, Moumdjian R, Béliveau R (2009) Propranolol adrenergic blockade inhibits human brain endothelial cells tubulogenesis and matrix metalloproteinase-9 secretion. Pharmacol Res 60:438-445. https://doi.org/10.1016/j.phrs.2009. 05.005

26. Lamy S, Lachambre M-P, Lord-Dufour S, Béliveau R (2010) Propranolol suppresses angiogenesis in vitro: inhibition of proliferation, migration, and differentiation of endothelial cells. Vasc Pharmacol 53:200-208. https://doi.org/10.1016/j.vph.2010.08.002

27. Moschovi M, Alexiou GA, Stefanaki K, Tourkantoni N, Prodromou N (2010) Propranolol treatment for a giant infantile brain cavernoma. J Child Neurol 25:653-655. https://doi.org/10. 1177/0883073810363917

28. PROPRANOLOL TEVA gélule - EurekaSanté par VIDAL. In: EurekaSanté. https://eurekasante.vidal.fr/medicaments/vidalfamille/medicament-opropa01-PROPRANOLOL-TEVA-gelule. html. Accessed 7 Apr 2018

29. Berti I, Marchetti F, Skabar A, Zennaro F, Zanon D, Ventura A (2014) Propranolol for cerebral cavernous angiomatosis: a magic bullet. Clin Pediatr (Phila) 53:189-190. https://doi.org/10.1177/ 0009922813492885

30. Cavalheiro S, Campos HG do A, Silva da Costa MD (2016) A case of giant fetal intracranial capillary hemangioma cured with propranolol. J Neurosurg Pediatr 17:711-716. https://doi.org/10.3171/ 2015.11.PEDS15469

31. Dotan M, Lorber A (2013) Congestive heart failure with diffuse neonatal hemangiomatosis-case report and literature review. Acta Paediatr (Oslo, Norway: 1992) 102:e232-e238. https://doi.org/10. 1111/apa.12184

32. Miquel J, Bruneau B, Dupuy A (2014) Successful treatment of multifocal intracerebral and spinal hemangiomas with propranolol. J Am Acad Dermatol 70:e83-e84. https://doi.org/10.1016/j.jaad. 2013.11.006

33. Reinhard M, Schuchardt F, Meckel S, Heinz J, Felbor U, Sure U, Geisen U (2016) Propranolol stops progressive multiple cerebral cavernoma in an adult patient. J Neurol Sci 367:15-17. https:// doi.org/10.1016/j.jns.2016.04.053

34. Goldberg J, Jaeggi C, Schoeni D, Mordasini P, Raabe A, Bervini D (2018) Bleeding risk of cerebral cavernous malformations in patients on $\beta$-blocker medication: a cohort study. J Neurosurg:1-6. https://doi.org/10.3171/2017.12.JNS172404 